\title{
Colombian agriculture under multiple exposures: a review and research agenda
}

Article

Accepted Version

Feola, G., Agudelo Vanegas, L. A. and Contesse Bamon, B. P. (2015) Colombian agriculture under multiple exposures: a review and research agenda. Climate and Development, 7 (3). pp. 278-292. ISSN 1756-5537 doi:

https://doi.org/10.1080/17565529.2014.934776 Available at https://centaur.reading.ac.uk/37274/

It is advisable to refer to the publisher's version if you intend to cite from the work. See Guidance on citing.

To link to this article DOI: http://dx.doi.org/10.1080/17565529.2014.934776

Publisher: Taylor and Francis

All outputs in CentAUR are protected by Intellectual Property Rights law, including copyright law. Copyright and IPR is retained by the creators or other copyright holders. Terms and conditions for use of this material are defined in the End User Agreement.

\section{www.reading.ac.uk/centaur}

\section{CentAUR}

Central Archive at the University of Reading 
Reading's research outputs online 


\title{
Colombian agriculture under multiple exposures: a review and research agenda.
}

\author{
Giuseppe Feola ${ }^{a *}$, Luis Alfonso Agudelo Vanegas ${ }^{b}$, Bernardita Paz Contesse Bamón ${ }^{c}$ \\ ${ }^{a}$ Department of Geography and Environmental Science, University of Reading, Whiteknights, RG6 6AB, United Kingdom \\ ${ }^{b}$ Fundación para la investigación el desarrollo e innovación (FIDI), Bogotá, Colombia \\ 'University of Reading, Whiteknights, RG6 6AB, United Kingdom \\ *Corresponding author: g.feola@reading.ac.uk
}

\begin{abstract}
We adopt the multiple exposures framework to review the existing literature on the impacts of climate change, trade liberalisation, and violent conflict on Colombian agriculture. These stressors act simultaneously but policies address them separately, overlooking the root causes of vulnerability. We find that the expected impacts of the single stressors have been relatively well documented, but that limited research has been dedicated to the observed effects of these three stressors and to their interactions. We propose a research agenda in three themes: trade-offs; social mechanisms; and governance. This agenda can inform not only agricultural adaptation but the debate on alternative agricultural development models. Keywords: Agriculture, Colombia, Climate Change, Trade Liberalisation, Conflict, Multiple Exposures
\end{abstract}

Resumen: En este artículo se utilizó el marco de exposición múltiple para revisar la literatura existente sobre el impacto que el cambio climático, la liberalización del comercio y los conflictos violentos tienen sobren la agricultura en Colombia. A pesar de que hay evidencia de que estos tres estresores actúan simultáneamente los discursos políticos respectivos tienden a proceder de forma separada. Asimismo, como estos discursos están dominados por un énfasis principalmente técnico, los procesos sociales, políticos y económicos que sustentan los sectores o unidades agrícolas vulnerables son generalmente desestimados. Esto se traduce en políticas de desarrollo rural y ambiental que no reconocen las complejidades propias de las dinámicas socio-ecológicas. En este artículo se sintetizaron los conocimientos existentes y se identificaron puntos clave, como por ejemplo cultivos, departamentos o sistemas de unidades agrícolas que parecen estar simultáneamente expuestos a los tres estresores previamente mencionados. Se mostró que los impactos tanto observados como esperados generados individualmente por cada estresor han sido relativamente bien documentados en la literatura existente, mientras que escasa literatura se ha desarrollado sobre las formas en que estos estresores interacciones entre si. Finalmente se identificaron tres importantes temas que, bajo un marco de exposición múltiple, deben ser incluidos en una agenda de investigación agrícola en Colombia: compensaciones mutuas, mecanismos sociales y gobernanza. De esta forma, la agenda agrícola podría no sólo informar sobre medidas de adaptación para la agricultura, si no que proponer una reconsideración de modelos alternativos para el desarrollo agrícola a la luz de un conocimiento profundo de la dinámica de los diversos sistemas agrícolas colombianos. Palabras clave: Agricutura, Colombia, Cambio climatico, Liberalización del comercio, Conflicto, Exposición multiple. 


\section{Introduction}

Agriculture is a fundamental sector of the Colombian economy and is considered by the government as one of five 'locomotives' of development in the country (Cárdenas and Rodríguez, 2013). Agriculture contributes to about $10 \%$ of the national gross domestic product (GDP) and employs $19 \%$ of the workforce nationally and $66 \%$ in rural areas (DANE, 2011). Colombian agriculture is facing both longstanding and more recent pressures, among which are climate change, trade liberalisation, and violent conflict, whose effects are expected to persist or grow in the next decades.

This convergence of stressors calls for integrated policies to strengthen the overall resilience of the agricultural enterprise and consequently its long-term sustainability, rather than the short-term response to single threats. However, the policy discourses on climate change, trade liberalisation, and violent conflict in Colombia mostly proceed separately (Cárdenas and Rodríguez, 2013). Particularly, the climate change discourse frames adaptation within existing social, economic, and political structures and reduces it to technical, informational, or economic measures (e.g., MADR, 2010; Ramirez-Villegas et al., 2013). Among the drawbacks of this approach are: (i) the lack of understanding of the root, or inherent, social, political, cultural, and economic causes of vulnerability, which might or might not be related to technology, economic incentives, or information; and (ii) the tendency to de-contextualise climate change, thus overlooking potential constraints, trade-offs, or synergies that may exist between actions in response to different stressors, as well as the role of non-agriculture-related actors whose involvement could be needed to enhance farming units' resilience (Feola, 2013, see also Peralvo et al., 2010). The farmer protests and agricultural strike that took place nationwide in August and September 2013 have once more drawn attention to the deeply ingrained vulnerability of Colombian smallholders, while at the same time exposing the downfalls of current models of development and the need for a reconsideration of policy priorities and goals to ensure the sustainable development of agriculture in Colombia (Cárdenas and Rodríguez, 2013).

In this paper, we adopt the multiple exposures framework (O'Brien and Leichenko, 2000; Leichenko and O'Brien, 2008) to review the existing evidence on the simultaneous impacts of climate change, trade liberalisation, and violent conflict on Colombian agriculture. The paper aims to assess the state of the art of the knowledge and the existence of studies addressing multiple exposures, or lack thereof. In so doing, the paper also aims to increase the awareness in the policy and research communities of the need to understand and act on such pressures in an integrated manner, and to identify important knowledge gaps for future research that can support sustainable agricultural development in Colombia.

[Figure 1 here]

\section{Theoretical background}

It is acknowledged that multiple stressors may concur with climate change to threaten the resilience and sustainability of social-ecological systems (e.g., O'Brien and Leichenko, 2000; Leichenko and O'Brien, 2008). As discussed by Leichenko and O'Brien (2008), globalisation and environmental change can interact in three fundamental ways (Table 1 ).

[Table 1 here]

For instance, farmers might have the knowledge, technological, or financial capacity to adapt to some climatic changes, but not to the simultaneous economic transition required by market liberalisation (or 
vice versa). It has also been observed that adaptive measures such as farming techniques that minimise risk from increased climate variability might restrict the scope for, or prevent entirely, adaptation to the needs for profitable commercial agriculture in a liberalised market (Silva et al., 2010). Vice versa, market liberalisation has been observed to modify vulnerability to drought-related food shortages, with some farmers becoming less vulnerable thanks to the participation in a more open market, but others becoming more vulnerable due to the removal of protectionist measures such as subsidies (Leichenko and O'Brien, 2002).

Vulnerability is therefore a condition that depends on how local and global change processes dynamically interact in locally specific social-ecological landscapes. The multiple exposures framework requires a shift from the development and analysis of technical adaptation measures to the understanding of the interplay of economic, political, cultural, and social processes that cause vulnerability in the first place (Ribot, 2011; Peralvo et al., 2010; Feola, 2013). Moreover, the multiple exposures framework calls for the consideration of ethical aspects (Paavola and Adger, 2006), whereby exposure, sensitivity, and adaptive capacity are often unevenly distributed and the 'winners' and 'losers' in different change processes may tend to coincide (Leichenko and O'Brien, 2008; O'Brien and Leichenko 2003). The ethical implications of agricultural adaptation are often overlooked, but can facilitate agreeing rights and responsibilities in adaptation policy (Grasso and Feola, 2012).

\section{Literature review}

\subsection{Multiple exposures}

Only few studies have investigated the challenge of adapting to simultaneous stressors in Colombian agriculture, and to the best of the authors' knowledge, no study so far has researched this issue systematically. In an early study, Dinar and Keck (1997) investigated private investment in irrigation and showed that the propensity to invest was reduced by the perception of increasing risk due to the simultaneous pressure of climate change, violent conflict, and trade and credit policies. In another study, Hertel et al. (2010) suggested that while climate change might reduce agricultural productivity and therefore affect farmer livelihoods, such a reduction might cause an increase in prices of agricultural commodities and in a liberalised trade system, this might mean higher income for farmer households, which could offset or even outweigh the loss of income caused by the reduced agricultural productivity.

\subsection{Impact of climate change on agriculture}

\subsubsection{Climate change in Colombia: overview}

Climate change is already occurring in Colombia, and it is likely to be exacerbated in the next decades (Pabón, 2003; Bradley et al., 2006; Ruiz, 2010). Ruiz (2010) projected that the highest changes in temperature would occur in the Caribbean and Andean regions, whereby the mean annual temperature could increase by $1^{\circ} \mathrm{C}$ to $6^{\circ} \mathrm{C}$ by mid-century (IDEAM et al., 2006; Magrin et al., 2007; Ruiz, 2010). Projections for rainfall had forecasted changes of +/- 15\% (IDEAM et al., 2006). As noted by Ruiz (2010), rainfall patterns may increase in some regions and decrease in others, with the most significant decrease in a 2011-2070 timeframe projected in the northern (i.e., Atlantic) and Amazonian regions. Freshwater supply in the Andean region is expected to decrease (Arce Rojas, 2011; Ruiz, 2010; Ruiz et al., 2008, 2011) as a result of changing precipitation patterns and rapidly melting glaciers; $80 \%$ of glacier mass is 
projected to disappear by 2050 (Costa Posada, 2007). Likewise, desertification is expected to advance rapidly in the Caribbean region, due to an increase in temperature and a decrease in rainfall (Vargas Cuervo and Gomez, 2003). Climate change is also considered responsible for more frequent and intense manifestations of the El Niño-Southern Oscillation (ENSO) cycles (Comunidad Andina, 2009), which have significant socio-economic and environmental impacts (Pabón and Torres, 2007; Poveda et al., 2011; Hoyos et al., 2013; Ruiz and Caicedo, 2013). The impacts of climate change on Colombian agriculture are diverse and include changes in crop phenology, flooding and salinisation of underground water due to sea level rise, changes in biotic factors (pests and diseases), land degradation and desertification, loss of plant genetic resources, and loss of crop and pasture suitability and productivity. Due to the country's geographical diversity, these impacts are expected to occur to varied degrees in different regions and crops (Ramirez-Villegas et al., 2013).

\subsubsection{Data}

Cline (2007) employed a combination of Ricardian and crop models to estimate the effect of climate change on wheat, rice, coarse grains, soybean, and oil seeds by 2080 , assuming that no adaptation was implemented. He indicated that the output per hectare was expected to decrease in Colombia, by 11.7 to $23.2 \%$ (reference year: 2003), depending on whether the carbon fertilisation effect was factored in the model or not, respectively. These estimates are consistent with those produced by Seo and Mendelsohn (2008), who projected reductions in smallholder farm household income in Latin America, taking into account possible adaptations, up to $14 \%, 20 \%$, and $53 \%$ of their income by 2010,2060 , and 2100 , respectively. In an earlier study on potato, Hijmans (2003) suggested that by 2040-59, the change in yield might range between -32.5 and $-30.6 \%$ with and without adaptation, respectively, and that $4.5 \%$ of the area studied might have an increased yield, independently of adaptation measures. Jones and Thornton (2003), on the other hand, studied maize by means of GCM crop model with a timeframe to 2055 , and found that yield would be essentially conserved.

More recent studies at the regional level in essence confirm Cline's negative scenario and add detail to the often stark differences among crops and regions. Eitzinger et al. (2012), Zapata-Caldas et al. (2012), and Ramirez-Villegas et al. (2013) used regional climate scenarios combined with ecological niche models such as EcoCrop and Maxent (Zapata-Caldas et al., 2012). Eitzinger et al. (2012) established the climate suitability index of 19 Colombian crops under an A2 emission scenario for central Colombia and for two different 30-year periods: 2020-2049 and 2040-2069. They found that climate suitability was likely to decrease by more than $29 \%$ by 2050 for papaya, guava, orange, mango, and plantain, which were considered the most affected crops, followed by corn, cassava, sugarcane, blackberry, tomato, potato, and bean, and banana (decreases of between $-2 \%$ and $-19 \%$ ). Climate suitability is expected to increase in this region and in this timeframe for rice $(+6 \%)$ and pea, onion, string bean, and coffee (all $+1 \%)$. Eitzinger et al. (2012) also intersected climate suitability data with land availability, including restrictions to land use, landscape protection, and proximity to access roads, and concluded that most crops were projected to lose area of highly favourable land by 2050, with exceptions represented by tomato, tree tomato, rice, bean, onion, and banana (Table 2). This study concluded that the expected climate change posed serious threats to the livelihoods of farmers supplying the capital Bogotá, and to the food security of the city and its region. Moreover, especially in the absence of adaptation measures, the change in crop suitability might force farmers to shift cultivation to higher altitudes which, in turn, would threaten forests and sensitive páramo ecosystems.

Zapata-Caldas et al. (2012) estimated that in the timeframes of 2020 and 2050, the crops with the most significant loss of climatic suitability (a more than $5 \%$ decrease) at the national level would be pea, barley, quinoa, wheat, and ulluco, while for potato, lettuce, carrots, and cucumber, a reduction in 
suitability between 0 and $-5 \%$ is expected. This study also concluded that some crops, among which are rice, banana and plantain, sorghum, tomato, and yuca would gain climate suitability ( $5 \%$ or more) (Table 2). Nevertheless, overall the areas affected negatively (loss of suitability) by climate change would be more extended than those affected positively. Zapata-Caldas et al. (2012) argued for an adaptation strategy based on multidisciplinary effort in assessment, technological development, extension and technology transfer, and crop insurance schemes.

Ramirez-Villegas et al. (2013) projected that with temperature increases of $2.5-3^{\circ} \mathrm{C}$, the proportion of land destined to crops would decrease. By and large, "if no adaptation measures are taken, $80 \%$ of crops would be impacted in more than $60 \%$ of their current areas of cultivation, with particularly severe impacts in high value perennial and exportable crops" (Ramirez-Villegas et al., 2013:1). Ramirez-Villegas et al. (2012) have identified crops that are mostly grown in areas where the expected temperature increase is $2.5-3^{\circ} \mathrm{C}$ (cocoa, dark tobacco, barley, soybean), and those mostly grown where the precipitation increase is expected to be in the range of $3-5 \%$ (coffee, sugarcane, flowers, fruits, plantain, rice, sorghum, barley, soybean), whereby a threshold of $3^{\circ} \mathrm{C}$ is considered critical for many crops. Similarly to Zapata-Caldas et al. (2012), Ramirez-Villegas et al. (2013) suggest that adaptation measures are urgently needed, particularly for smallholders. They propose an adaptation strategy based on the generation and increase in accessibility of information (e.g., climate impact assessments), technical development, institutional restructuring, and inter-institutional networks.

Other scholars studied the effect of climate change on livestock farming. Seo et al. (2010) applied a multinominal logit model for evaluating the effects of climate change under three different scenarios on beef cattle, dairy cattle, pigs, sheep, and chickens. Seo et al. (2010) projected a reduction (up to 10\%) in dairy cattle and an increase (up to $20 \%$ ) in sheep farming, the latter being predicted to be a livelihood strategy adopted particularly in the Andean region. Thus, Seo (2010) suggested that the possibility of switching from one agricultural system to another could be a way of using climate change in favour of agriculture.

In another study, Seo (2010) assessed by means of a micro-econometric analysis the effect of climate change on land value in three agricultural systems: crop, livestock, and a mixed system. Seo (2010) suggested that under a hot and dry scenario, farmers tended to change from a crop specialised system towards a mixed one, while under a milder but wetter scenario, farmers tended to switch from livestock to crops. Additionally, Seo (2010) suggested that under severe climate variations, land value of a specialised crop farm would decrease by about $20 \%$, while the value of an integrated mixed farm would decrease only by about 10\%, with direct effects on the farmer's livelihood. On account of this, Seo (2010) suggested that each type of farm would present important differences regarding their vulnerability to climate change, with the integrated farm being more resilient to intense climate changes.

[Table 2 here]

\subsection{Impact of trade liberalisation on agriculture}

\subsubsection{Trade liberalisation in Colombia: overview}

Since the 1990s, the Colombian government has promoted economic liberalisation (Gracia and Zuleta, 2005; Trovar, 2011), on the assumption that the exposure of local markets to competition from regional and global ones would attract foreign investment, promote innovation and efficiency, and thus favour both the productive sector and consumers (Balcázar, 2003; Forero, 2010; Jaramillo, 2001). As a result, 
the proportion of exports as a share of GDP has increased by 5-10\% of GDP (Gracia and Zuleta, 2005). Liberalisation has favoured the supply of cheap food to the growing urban middle class, but has been accompanied by a lack of social, economic, and political recognition of peasants and reinforced their marginalisation in favour of a neo-liberal model of development (Petras and Veltmeyer, 2002; Forero, 2003; Forero, 2010). Market-led agrarian reforms (Borras, 2003; De Los Rios, 2011) have reinforced an inequitable and inefficient land distribution and use, whereby shrinkage of land dedicated to food production contributes to the increasing need of Colombia for food imports (Richani, 2012). Eighty per cent of the holdings in Colombia are smallholdings, with peaks in the Andean regions, and $80 \%$ of the agricultural land is possessed by $10 \%$ of land owners (Perez and Perez, 2002). Furthermore, it is estimated that $18 \%$ of land owners do not have formalised property rights and that $65 \%$ of agricultural workers live in poverty conditions (Deininger and Lavadenz, 2004; UNDP, 2011).

Colombia has signed bilateral or regional free trade agreements (FTAs) with several countries in the Americas, the Pacific region, and the European Union (Arguello, 2009). The bilateral FTA with the USA entered into force on 15 May 2012 and entailed the minimisation or progressive elimination of subsidies and tariffs. However, one of the most significant challenges of the FTA was the marked asymmetry between the two national economies, in particular concerning the agri-food sector which, according to some, has not been taken sufficiently into consideration (Barrera, 2005; Santisteban, 2008; Villareal, 2012).

\subsubsection{Data}

In 2004, a study of the Ministry of Environment and Sustainable Development (MADR) concluded that the possibilities to increase the export of the 10 main agricultural export products, including banana, coffee, and flowers were minimal, whereas the USA was likely to expand the export of their products in Colombia (MADR, 2004). Based on an analysis of a competitiveness index, the study identified in bovine meat, sugar, fruit and vegetables, and tobacco the Colombian products with the potential to benefit from the FTA, and in poultry meat, rice, oil seeds, cotton, and bean those that were at risk of strong and potentially overwhelming competition from imports (MADR, 2004). However, the results regarding bovine meat were indirectly challenged by Gil Quintero (2008), who argued that the Colombian livestock industry was expected to experience negative effects of the FTA because of its lack of competitiveness, poor export capacity, and reliance on imported technologies (Table 3).

Similarly, by using a computable general equilibrium model, Gracia and Zuleta (2005) estimated that the FTA might have a minor but positive economic impact overall in terms of income and consumer prices. However, they expected negative consequences for the agricultural sector, particularly with respect to cereals and oil seeds, which might see an increase in import (141.3 and $153.6 \%$, respectively) in the face of much smaller increases in export ( 9.3 and $84.6 \%$, respectively). While they estimated a reduction in consumer prices of $2-2.5 \%$ for these products, they also expected a $6.4 \%$ decrease in production for cereals and a $7.5 \%$ increase in production for oil seeds. Gracia and Zuleta (2005) suggested that unless the infrastructure (i.e., internal transport routes, ports) was improved to make Colombia an economic unity, and if the share of skilled labour was not increased, the benefits and costs of the FTA would be unequally distributed in the country. These conclusions were also reached by Martincus and Gomez in a later study (2009).

The spatial differentiation of the impacts of the FTA on Colombian agriculture was also studied by Arguello (2009), who adopted a two-step procedure that combined a computable general equilibrium model (2001 base year) and a transportation model. He found that allocative efficiency might increase but the terms of trade were reduced, with a total gain in welfare of about $0.45 \%$ over current GDP. The 
results of this modelling exercise suggest that the gains and losses of trade liberalisation tend to concentrate in a few regions due to: (i) different production costs and proximity to markets (given the high transport costs within the country); (ii) uneven tariffs on importable agricultural inputs; and (iii) the composition of regional production, which determines the level of competition from imports. Regarding the impacts on crops, Arguello (2009) estimated a decrease in internal production of paddy rice, cereals, and oil crops of $11.9,13.2$, and $12.9 \%$, respectively.

Garay et al. (2009) used a producer surplus model to estimate the impacts of the FTA for different crops or livestock species and types of farming units, with particular focus on smallholder agriculture. The results suggested a significant reduction of price (20 to 55\%), area cultivated (19 to $77 \%$ ), production (18 to $54 \%$ ), and value of production (35 to $79 \%$ ) for rice, maize, sorghum, wheat, and bean. Pea, onion, tomato, and carrot were expected to register a reduction in price and value of production of $15 \%$, while poultry and pork meat were projected to register a reduction in price (51 and 28\%, respectively), production ( 35 and 51\%, respectively), and value of production (65 and 68\%, respectively) (Garay et al., 2009).

Garay et al. (2009) also estimated the percentage of smallholding agricultural units that were exposed to different levels of competition with imports from the USA, and the expected change in gross and net income and producer surplus under three scenarios of prices and exchange rates. Garay et al. (2009) concluded that while the FTA presented opportunities to increment export of some products to the USA, the realisation of those opportunities depended on progress made in increasing the competitiveness of Colombian agriculture (including transport infrastructure) and its adaptation to international sanitary and phytosanitary standards. The structural changes are costly and require investments that are out of reach of most smallholders (Garay et al., 2009), especially under conditions of increased price volatility that are expected with the elimination of tariffs and price bands (Hansen Kuhn, 2011).

Finally, several studies investigated the expected impacts of the FTA on specific regions or crops. The United Nations Environment Programme (UNEP) (2005) focussed on corn and estimated that the FTA would cause (compared with the average for the years 1998-2002) a reduction in prices (17.4 to $32.1 \%$ ) and consequently of areas cultivated with this crop (9.2 to $17.8 \%$ ), production ( 8.2 to $15.9 \%$ ), value of production ( 24.1 to $42.8 \%$ ), income for producers ( 24.1 to $42.8 \%$ ), and workforce employed and workers' income (both 9.2 to $17.8 \%$ ). The regions that were expected to be most heavily affected by the FTA in terms of reduction in number of producers, areas cultivated, and workforce were Bolívar, Antioquia, Cesar, Cundinamarca, Córdoba, Santander, Magdalena, Nariño, and Huila for the traditional smallholding units, and Córdoba, Valle, Meta, Sucre, Tolima, and Antioquia for the industrial medium- to large-holder units.

The effects of the FTA on the region of Bolívar were projected by López and Sáenz (2008) using comparative advantage indexes. In this study, it was found that some fruits (cherries, apricots), beans, and vegetable, sorghum, and soy seeds were among the products considered to be more exposed to competition from the USA. Potentially, up to $69 \%$ of the producers for the internal market were considered to be highly or moderately exposed to imports from the USA. In another study on vegetable and fruit production, the Chamber of Commerce of Bogotá (2007) used a general equilibrium model and a value-chain analysis to determine that this produce had a potential for export. Similar to the results of other studies, however, the need for technological improvement and value-chain coordination were considered essential to realise the opportunity created by the FTA (CCB, 2007). Similar conclusions were reached for the milk value-chain that has historically been oriented towards the national market (CCB, 2007). Solarte et al. (2006) reached similar conclusions for the milk value-chain in the region of Nariño. They concluded that while there was the potential for milk producers to export to the USA, the capacity 
to do so was extremely limited due to technological constraints and health and phytosanitary standards, which were particularly strict in the case of milk and milk products and difficult to meet by small producers in this region.

[Table 3 here]

\subsection{Impact of violent conflict on agriculture}

\subsubsection{Violent conflict in Colombia: overview}

Violent conflict has been deeply rooted in Colombia's history since the emancipation from the Spanish colonial power. Two closely interconnected types of violent conflict can be pointed out in rural areas at present: agrarian conflict and political violence. The former is related to the markedly unequal distribution of land and property rights that characterises the country. The latter, despite originating from a peasant movement for access to land, escalated into the cultivation of illicit crops, drug trafficking, and violent political confrontation (UNDP, 2003; Grajales, 2011; Thomson, 2011; GMH, 2013). Despite the overall positive first outcomes of the recently renewed peace talks between the Colombian government and the major revolutionary group, the Revolutionary Armed Forces of Colombia-People's Army (FARC), thousands of households are still being displaced and hundreds of communities in the country suffer from the consequences of decades of violent conflict (UNDP, 2003, 2011).

Violent conflict in Colombia claimed at least 220,000 deaths, of which $81.5 \%$ were civilians, between 1958 and 2012 (GMH, 2013). In addition, 25,007 people were reported as disappeared and, only between 1970 and 2010, 27,023 people were kidnapped (GMH, 2013). Thousands of civilians were also victims of sexual violence and anti-personnel mines, and thousands of children were recruited by illicit groups (GMH, 2013). Violent conflict has been shown to have negative effects on economic growth in Colombia (Riascos and Vargas, 2011), and disrupting impacts on rural life through several mechanisms, which include farm households being caught in an armed conflict, the diversion of public resources away from social programmes in rural areas and toward expenditures on police and military control, the disruption of in- and off-farm activities (e.g., transportation, access to buying inputs, marketing outputs), the environmental and health effects of the government's aerial herbicide spraying, the distortion of market and land prices, the emotional and moral (i.e., humiliation, stigmatisation) impact on people, and the rupture of social bonds and trust (Gonzales and Lopez, 2007; GMH, 2013; Pinilla, 2013). The governmental programmes implemented to ensure security have often been more successful in protecting institutions than the general rural population (Elhawary, 2010), and it has been found that farmers respond to the uncertainty and risk associated with violent conflict by limiting their activities to those of low risk, which also have low return, to avoid possible economic and physical capital losses (Arias and Ibáñez, 2012; Pinilla, 2013).

\subsubsection{Data}

Gonzales and Lopez (2007) investigated the impact of political violence on agricultural efficiency by employing a stochastic input-oriented distance function coupled with an equation for the determinants of inefficiency that included local violence and other environmental indicators as explanatory variables. They convincingly showed that political violence increased technical inefficiency. Their simulations suggested that "eliminating violence would increase farm household efficiency by an average of 10\%" (Gonzales and Lopez, 2007:385) which, according to their model, would translate to a $10 \%$ increase in producer surplus. These results were confirmed by Pinilla (2013), who analysed country-level data and 
concluded that violent conflict was associated with a reduction in productivity of between $13 \%$ (permanent crops) and $25.9 \%$ (temporary crops), whereby smallholders and the crops of coffee, plantain, and fruits were identified to suffer most of these reductions. He argued that the end of conflict and the inclusion of currently non-cultivated land in production would correspond to a $5.8 \%$ increase of agricultural GDP and a $0.37 \%$ increase of national GDP. Pinilla (2013) also showed that informal land property rights and narcotrafficking were two main drivers of the impact of violent conflict on agriculture, especially for smallholders. Gonzales and Lopez (2007) showed that political violence tended to affect large farm efficiency more than small farm efficiency, which may be explained by several factors, such as a higher probability of these farms to be targeted by violent groups (e.g., kidnappings, extortion) or their higher dependency on hired labour. Furthermore, political violence seemed to affect livestock farms less than other farm types, which might be explained by their lower reliance on hired labour and relative asset mobility.

Perez (1998) identified the presence of illegal groups and violent conflict as one of the factors preventing rural development in Colombia (see also Perez and Perez, 2002) and took the percentage of municipalities with land acquisitions by narcotrafficking groups as an indicator of their spread and presence. While there is debate on the correlation between illegal groups and violence (Holmes et al., 2006), Perez calculated that an average of $42 \%$ of municipalities in Colombia had seen land acquisitions by narcotrafficking groups, but the variation among regions was wide, with the regions of Valle and Córdoba with more than $80 \%$ and Norte de Santander and Nariño with less than $10 \%$ of municipalities affected by this phenomenon (Table 4).

It is estimated that violent conflict, including aerial herbicide spraying to eradicate illicit crops caused the displacement of $4,700,000$ and 5,700,000 people in Colombia (GMH, 2013). In most cases, forced displacement implied the loss of agricultural land, technical capital, livestock, and other goods, besides the disruption of the social network and way of life (Kirchhoff and Ibañez, 2001; Ibanez and Velasquez, 2008). Displacement affected 6.6 million hectares of agricultural land, equal to $15 \%$ of total agricultural land in the country, and mostly small- and medium-holders (UNDP, 2011). While violent conflict affected all regions in different forms and at different times, its effects as measured by different indicators (i.e., selective killings, political homicides, massacres, forced disappearances, kidnappings, anti-personnel mines, sabotage and acts of violence against public goods, and killing of peasant leaders) followed a consistent geographical pattern, as shown in Table 4 (UNDP, 2011; GMH, 2013).

[Table 4 here]

\section{Discussion}

\subsection{State-of-the-art knowledge}

This review showed that the expected impacts of the single stressors have been relatively well documented in the literature. Despite the fact that knowledge gaps still exist, it seems safe to say that research has started to build a knowledge base on the challenges that Colombian agriculture is facing under each of these three stressors.

However, as the effects of the three stressors and especially climate change and trade liberalisation manifest themselves on the ground, there is room for improving our understanding of the observed, rather than projected, impacts. Furthermore, it is apparent from this review that very limited research has been dedicated to the interactions of the distinct stressors. The study by Dinar and Keck (1997) 
reviewed in this paper is a clear example, albeit of limited scope and almost unique for Colombia, that farmers' decision in practice reflect not one, but a complex landscape of stressors and system characteristics. However, this review showed that the impacts of climate change, trade liberalisation, and violent conflict, respectively were usually studied under the implicit assumption of 'everything else being equal'. In fact, this is an oversimplification that masks the interlinked technical, economic, social, and political processes that determine the exposure and vulnerability of different crops, regions, and agricultural units, and with it the unequally distributed ability to respond (or the vulnerability) of particular social groups to the simultaneous stressors.

The review also highlighted units of analysis that seemed to be particularly affected by observed or expected impacts of simultaneous climate change, trade liberalisation, and violent conflict. Smallholders were almost unanimously identified as more exposed, and possibly more vulnerable, than large holders. On the other hand, it was difficult to identify hotspot regions, because they are very diverse in terms of agro-ecological zones, production systems, and human communities. Several crops were expected to be impacted negatively by both trade liberalisation and climate change and might represent priorities for research and action: bean, carrot, maize, oil seeds, and wheat. On the other hand, some crops were expected to be impacted positively or negatively by these two stressors: fruits, vegetables, tomato, plantain, sorghum, and bovine, sheep, and chicken meat. In addition, several crops that are exposed to climate change, trade liberalisation, or both are mostly cultivated in regions that have experienced major effects of violent conflict (Table 4): yuca, rice, sugarcane, bean, soybean and, to a lesser but still significant extent, also banana and plantain, cacao, maize, and cotton (MADR, 2011). For these crops and produce, the limits of a single-focused analysis are even more evident, as the prioritisation of adaptation measures based on one focus of analysis (i.e., climate change) collides with that based on a different focus (i.e., trade liberalisation or violent conflict) (Table 5).

[Table 5 here]

\subsection{A research agenda for Colombian agriculture under multiple exposures}

We propose here three broad and interdisciplinary research themes that emerge from this review: tradeoffs, social mechanisms, and governance. We suggest that they represent urgent knowledge gaps, and can orient future research on observed impacts of simultaneous stressors on Colombian agriculture and inform sustainable agricultural development.

\subsubsection{Trade-offs}

This review highlighted the lack of evidence or projections on how the positive and negative impacts of distinct stressors played out in practice, or how the adaptation measures taken to respond to different stressors would interact under the specific conditions of distinct agricultural systems. Answering these and similar questions entails considering the 'outcome', 'context', and 'feedback' of multiple exposures (Leichenko and O'Brien, 2008) (Table 1) and assessing the potential synergies or trade-offs generated by expected impacts and a range of alternative responses. The trade-offs can involve multiple dimensions, such as economic, technical, or social (Feola, 2013), which call for methodologies that enable consideration of such multidimensionality, for example, multi-criteria assessment (Munda, 2005) or trade-off modelling (Stoorvogel et al., 2004). In addition, trade-offs can cross social groups and temporal and spatial scales, thus calling into question also ethical considerations that determine winners and losers from adaptation (O'Brien and Leichenko, 2003). Such a trade-off assessment does not need to be limited to the farm level, but can have important implications at the regional and national levels. In the 
present context of conflicting development models and goals (Carrizosa Umaña, 2013) it can, for example, help to identify the potential clashes between the policy objectives of economic development, as pursued through trade liberalisation and market-based modernisation, and climate change adaptation.

\subsubsection{Social mechanisms}

It has been shown that development and agricultural policies often are not based on an in-depth understanding of the adaptation mechanisms adopted by farmers on the ground (e.g., Feola et al., unpublished). A sound understanding of farmers' actions includes a range of factors across scales, and how actions produce and re-produce practices that are adaptive to the social as well as the natural environment, as perceived by the farmer (Feola et al., unpublished). This is different from quantifying and assessing impacts and vulnerabilities, in that the focus is on decision-making processes under the experience of changing conditions (Smit and Wandel 2006:285). This includes the notions of 'dynamic vulnerability' and 'dynamic adaptation' (e.g., Meza and Silva, 2009; Westerhoff and Smit, 2009), which stress the changing nature of the pressures farmers are facing and the dynamic nature of the adaptation process in coupled social-ecological systems. Such a perspective opens up opportunities for investigation of the social mechanisms of response to multiple exposures in Colombian agriculture, i.e., to understand how and why specific farming practices persist over time or are dropped in favour of different ones, and how these practices are influenced by, and in turn influence, social and biophysical structures under multiple simultaneous exposures (Feola, 2013b). What social-ecological processes characterise different Colombian agricultural systems under multiple exposures? Are Colombian farmers adapting to multiple stressors, and how? How do farmers make adaptation decisions in the face of multiple exposures? How and why do farming practices change in different contexts? By answering these questions, it is possible to identify the means to support adaptive capacity where and when needed by different farming units in distinct local systems, build awareness of the pathways to impact as perceived and understood by the system actors, and uncover the social mechanisms underlying maladaptive practices, including issues of power (Scoones, 2009; Ribot, 2011) and transformation of social, political structures (e.g., land property rights) that are marginalising or constraining farmers' adaptive capacity.

\subsubsection{Governance}

In Colombia it has been historically difficult to achieve institutional integration, i.e., to effectively coordinate the responsibilities and actions of different levels of government and across different sectors (e.g., environmental, economic) (Ryan, 2012; Andrade, 2013). This has contributed to reinforcement of patterns of social, economic, and political exclusion of smallholders and peasant communities (Perez and Perez, 2002; Forero, 2010), which is at the root of the vulnerability of large sections of rural Colombia, and calls into question issues of procedural and distributive justice (Paavola and Adger, 2006; Grasso and Feola, 2012). The latter are particularly relevant in a country characterised by such a high environmental, technical, social, and economic variability, disconnection among regions due to poor infrastructure (Gracia and Zuleta, 2005; Arguello, 2009; Garay et al., 2009; Martincus and Gomez, 2009), and the consequent unevenly distributed capacity to respond to stressors. The paradigm of territorial governance (Perez, 2004; De los Rios, 2008; Machado, 2010; Andrade, 2013; Garay et al., 2013) has recently received attention. It focuses on the territory as a unifying concept, and on human security as an integrative framework to understand the primary causes of vulnerability, thus counterweighing the emphasis placed on environmental and technical dimensions. However, how this paradigm could be practically translated on the ground in diverse regions is still an open issue. Furthermore, the lack of a conceptual framework that considers the simultaneous impact of different stressors in agriculture can generate a public resource competition between state agencies, isolating their work and favouring the 
compartmentalisation of the knowledge produced by each of them (see also Ramirez-Villegas et al., 2013). Against this backdrop, a range of questions appear to be open to further investigation. What paradigms are most appropriate to consider the complexity of Colombian agricultural systems, including both their social (e.g., cultural) and environmental (e.g., ecosystem services) dimensions? What institutional arrangements allow governing the complexity of multiple exposures across spatial and temporal scales? What frameworks and principles can inform the just allocation of resources to reduce vulnerability and respond to multiple exposures?

\section{Conclusions}

Together with a focus on observed rather than projected effects, the three themes of trade-offs, social mechanisms, and governance, and the respective research questions presented above represent a research agenda that emerges urgently from this review. This agenda will hopefully stimulate an integrated perspective on agriculture in the face of multiple exposures and encourage the breaking down of disciplinary borders. Therefore, this review contributes to the ongoing debate on climate change, trade liberalisation, and violent conflict in Colombia, draws attention towards the inherent interconnections among these issues, and synthesises the state-of-the-art knowledge from which to move forward to produce an understanding of agricultural systems that can support agriculture in the face of multiple exposures. Finally, by purposively going beyond a technical-fix and sectorial approach, this agenda can inform not only agricultural adaptation, but a reflection on alternative rural development models, which are essential for fostering a process of rural transformation and the pursuit of sustainability in Colombian agriculture.

\section{Acknowledgments}

The authors are grateful to the Cartographic Research Laboratory at the University of Alabama for providing the map of Colombia, and to Amy Lerner for her comments on a previous version of this manuscript. This research was funded by the Walker Institute for Climate Impacts Research at the University of Reading through the Research Development Fund, and the British Academy and the Leverhulme Trust through a Small Research Grant.

\section{References}

Andrade, G., 2013. La construcción de paisajes sostenibles y resilientes en intensificación agrícola de la altillanura colombiana, oportunidad que se desvanece. Desarrollo Económico y adaptación al cambio climático, Cárdenas, M., Rodríguez, M. (eds.). Frescol and Foro Nacional Ambiental, Bogotá, Colombia. 129-160.

Arce Rojas, R., 2011. Adaptación al Cambio Climático. Una perspectiva regional: Sistematización del diálogo regional de adaptación y de aprovechamiento de aguas de la agricultura al cambio climático en los Andes. GIZ y Ministerio Federal de Cooperación Económica y Desarrollo, Lima, Perú.

Arguello, R., 2009. The Regional Impact of Discriminatory Trade Liberalization on Colombian Agriculture. The Journal of Regional Analysis and Policy, 39. 155-173. 
Arias, M.A., Ibáñez, A.M., 2012. Conflicto armado en Colombia y producción agrícola: ¿aprenden los pequeños productores a vivir en medio del conflicto? (No. 44), Documentos CEDE. Centro de Estudios sobre Desarrollo Económico, Universidad de los Andes, Bogota, Colombia.

Balcázar, Á., 2003. Transformaciones en la agricultura colombiana entre 1990 y 2002 . Revista de Economia Institucional, 5. 128-145.

Barrera, E.B., 2005. La agricultura colombiana y el TLC con Estados Unidos. Oasis, 10. 279-297.

Borras, S.M., 2003. Questioning the Market-Led Agrarian Reform: Experiences from Brazil, Colombia and South Africa. Journal of Agrarian Change, 3(3). 367-394.

Borras, S.M., Franco, J.C., Gómez, S., Kay, C., Spoor, M., 2012. Land grabbing in Latin America and the Caribbean. The Journal of Peasant Studies, 39. 845-872.

Bradley R.S., Vuille M., Diaz H.F. and Vergara W., 2006. Threats to Water Supplies in the Tropical Andes. Science 312. 1755-1756. DOI: 10.1126/science.1128087.

Brown, K., 2011. Sustainable adaptation: An oxymoron?. Climate and Development, 3(1). 21-31.

Cárdenas, M., Rodríguez, M. (eds.) 2013. Desarrollo Económico y adaptación al cambio climático, Frescol and Foro Nacional Ambiental, Bogotá, Colombia.

Carrizosa Umaña, J., 2013. Cambio climático y locomotoras del desarrollo. Desarrollo Económico y adaptación al cambio climático, Cárdenas, M., Rodríguez, M. (eds.). Frescol and Foro Nacional Ambiental, Bogotá, Colombia. 15-28.

Chamber of Comerce of Bogota/Cámara de Comercio de Bogota. (2007). Impacto económico del TLC con Estados Unidos en la región Bogotá-Cundinamarca. Bogota: Author.

Cline, W. R., 2007. Global warming and agriculture: end-of-century estimates by country. Peterson Institute, Washington DC, USA.

COMUNIDAD ANDINA, 2009. Articulando la gestión del riesgo y la adaptación al cambio climático en el sector agropecuario: lineamientos generales para la planificación y la gestión sectorial. PRECAN, Lima, Perú.

Costa Posada, C., 2007. La adaptación al cambio climático en Colombia. Revista de Ingeniería, 26. 74-80.

DANE, 2011. Statistical database, Estadística DANd (ed.). DANE, Bogotá.

De Los Rios, J.C., 2008. La agricultura latinoamericana y sus posibilidades de adaptación a los cambios climáticos globales. Interfaces em Desenvolvimento, Agricultura e Sociedade 2(1), 53-75.

De Los Rios, J.C., 2011. Reforma agraria en Colombia: evolución histórica del concepto. Hacia un enfoque integral actual. Cuadernos de Desarrollo Rural 8(67). 93-119.

Deininger, K., Lavadenz, I., 2004. Colombia: política agraria en transicción (No. 55), En breve. World Bank, Washington DC, USA.

Dinar, A., Keck, A., 1997. Private irrigation investment in Colombia: effects of violence, macroeconomic policy, and environmental conditions. Agricultural Economics, 16. 1-15. 
Eitzinger, A., Läderach, P., Bunn, C., Quiroga, A., Benedikter, A., Pantoja, A., Gordon, J. and Bruni, M., 2012. Implications of a changing climate on food security and smallholders' livelihoods in Bogotá, Colombia. Mitigation and Adaptation Strategies for Global Change, 19:1-16.

Elhawary, S., 2010. Security for whom? Stabilisation and civilian protection in Colombia. Disasters, 34. 388-405.

Feola, G., 2013. What (science for) adaptation to climate change in Colombian agriculture? A commentary on "A way forward on adaptation to climate change in Colombian agriculture: perspectives towards 2050" by J. Ramirez-Villegas, M. Salazar, A. Jarvis, C. E. Navarro-Valcines. Climatic Change, 119(3-4). 565-574.

Feola, G. 2013b. Models of human behaviour in social-ecological systems in International Social Science Council (ISSC) and United Nation Educational Scientific and Cultural Organization (UNESCO) The World Social

Science Report 2013: Changing Global Environments: Transformative Impact of Social Sciences, UNESCO Publishing.Feola, G., Lerner, A., Jain, M., and Montefrio, M.J.F., Nicholas, K.A., Farmers responses to multiple stresses in the face of global change: Assessing five case studies to enhance adaptation.

Forero, J., 2003. Economia campesina y sistema alimentario en Colombia: Aportes para la discusion sobre seguridad alimentaria. Memorias Seminario regional Desarrollo rural y soberanía alimentaria

Forero, J., 2010. Economia campesina, pobreza, tierra y desplazamiento en Colombia. In: Forero J (ed) EI campesino colombiano: entre el protagonismo economico y el desconocimiento de la sociedad. Pontificia Universidad Javeriana, Bogota, 69-119.

Garay, L.G., Bailey, R., Forero, J., Barberi, F., Ramírez, C., Suárez, D.M., Gómez, R., Castro, Y., Álvarez, J.M., Roldán, R., Sánchez, E., Machado, A., Salgado, C., Naranjo, S., Perry, S., 2013. Reflexiones sobre la ruralidad y el territorio en Colombia. Problematicas y retos actuales. Oxfam Colombia, Bogotá, Colombia.

Garay, L.J., Gómez, F., Landínez, I., 2009. Impact of the US-Colombia FTA on the small farm economy in Colombia. Research Report. Oxfam International, Bogotá, Colombia.

Gil Quintero, J.D., 2008. TLC, Globalización, y el futuro de la ganaderia en Colombia. El Cuaderno, 2. 2351.

González, M.A., Lopez, R.A., 2007. Political Violence and Farm Household Efficiency in Colombia. Economic Development and Cultural Change, 55. 367-392.

Gracia, O., Zuleta, H., 2005. The Free Trade Agreement between Colombia and USA: what can happen to Colombia? Presented at the DEGIT X, Mexico.

Grajales, J., 2011. The rifle and the title: paramilitary violence, land grab and land control in Colombia. The Journal of Peasant Studies, 38. 771-792.

Grasso, M. and Feola, G., 2012. Mediterranean agriculture under climate change: adaptive capacity, adaptation, and ethics. Regional Environmental Change, 12(3). 607-618.

Grupo de Memoria Historica (GMH), 2013. ¡BASTA YA! Colombia: Memorias de guerra y dignidad. Imprenta Nacional, Bogotá, Colombia. 
Hansen-Kuhn, K., 2011. The U.S.-Colombia trade agreement: A volatile agenda on agriculture. Institute for Agriculture and Trade Policy, Minneapolis, USA.

Hertel, T.W., Burke, M.B., Lobell, D.B., 2010. The poverty implications of climate-induced crop yield changes by 2030. Global Environmental Change, 20, 577-585.

Hijmans, R. J., 2003. The effect of climate change on global potato production. American Journal of Potato Research, 80(4). 271-279.

Holmes, J.S., de Piñeres, S.A.G., Curtin, K.M., 2006. Drugs, Violence, and Development in Colombia: A Department-Level Analysis. Latin American Politics and Society, 48. 157-184.

Ibáñez, A.M., Velásquez, A., 2008. El impacto del desplazamiento forzoso en Colombia: condiciones socioeconómicas de la población desplazada, vinculación a los mercados laborales y políticas públicas (No. 145), Políticas sociales. United Nations, Social Development division, Santiago de Chile, Chile.

IDEAM, UNDP and Ministerio De Ambiente Vereda y Desarrollo Territorial, 2006. Estrategias de reducción de incertidumbre de las variables básicas de la estimación de Gases de Efecto Invernadero (GEI). Bogotá, Colombia.

Jaramillo, C.F., 2001. Liberalization, Crisis, and Change: Colombian Agriculture in the 1990s. Economic Development and Cultural Change, 49. 821-846.

Jones, P. G. and Thornton, P. K., 2003. The potential impacts of climate change on maize production in Africa and Latin America in 2055. Global Environmental Change, 13(1). 51-59.

Kirchhoff, S., Ibañez, A.M., 2001. Displacement due to Violence in Colombia: Determinants and Consequences at the Household Level (No. 41), ZEF - Discussion Papers on Development Policy. Center for Development Research, University of Bonn, Bonn, Germany.

Leichenko, R. M. and O'Brien, K. L., 2008. Environmental Change and Globalisation: Double Exposures. Oxford University Press, Oxford, UK.

Leichenko, R.M. and O'Brien, K.L., 2002. The Dynamics of Rural Vulnerability to Global Change: The Case of southern Africa. Mitigation and Adaptation Strategies for Global Change, 7(1). 1-18.

López, L.F., Sáenz, J.A., 2008. Sectores y productos sensibles en Bolívar frente al TLC con Estados Unidos. Cámara de Comercio de Cartagena, Cartagena de Indias, Colombia.

Machado, A. (2010). Lessons on rural development, challenges and approaches. Agronomia Colombiana, $28,437-443$.

Magrin, G., C. Gay García, D. Cruz Choque, J.C. Giménez, A.R. Moreno, G.J. Nagy, Nobre, C. and Villamizar, A., 2007. Latin America. Climate Change: Impacts, Adaptation and Vulnerability. Contribution of Working Group II to the Fourth Assessment Report of the Intergovernmental Panel on Climate Change, Chang, M.L. Parry, O. F. C., J.P. Palutikof, P.J. Van Der Linden and C.E. Hanson (ed.). Cambridge University Press, Cambridge, UK. 581-615.

Martincus, C.V., Gómez, S.M., 2009. Trade Policy and Export Diversification: What Should Colombia Expect from the FTA with the United States (No. 136), IDB Working Paper series. Inter-American Development Bank. 
McDowell, J.Z. and Hess, J.J., 2012. Accessing adaptation: Multiple stressors on livelihoods in the Bolivian highlands under a changing climate. Global Environmental Change, 22(2). 342-352.

Meza, F. and Silva, D., 2009. Dynamic adaptation of maize and wheat production to climate change. Climatic Change, 94(1-2). 143-156.

Ministerio de Agricultura y Desarrollo Rural (MADR), 2004. El agro Colombiano frente al TLC con Estados Unidos. Ministerio de Agricultura y Desarrollo Rural, Bogota, Colombia.

Ministerio de Agricultura y Desarrollo Rural (MADR), 2010. Balance de Gobierno Logros y Retos del Sector Agropecuario 2002 - 2010. Ministerio de Agricultura y Desarrollo Rural, Bogota, Colombia.

Ministerio de Agricultura y Desarrollo Rural (MADR), 2011. Anuario estadistico 2011. Bogota, Colombia.

Munda, G., 2005. "Measuring Sustainability": A Multi-Criterion Framework. Environment Development Sustainability, 7(1). 117-134.

O'Brien, K.L. and Leichenko, R.M., 2000. Double exposure: assessing the impacts of climate change within the context of economic globalization. Global Environmental Change, 10(3). 221-232.

O'Brien, K.L. and Leichenko, R.M., 2003. Winners and Losers in the Context of Global Change. Annals of the Association of American Geographers, 93(1). 89-103.

Paavola, J. and Adger, W.N., 2006. Fair adaptation to climate change. Ecological Economics, 56(4). 594609.

Pabón, J.D., 2003. El Cambio Climático Global y su Manifestación en Colombia. Cuadernos de Geografía, 12(1-2). 111-119.

Pabón, J. D., \& Torres, G. (2007). Impacto socioeconómico de los fenómenos El Niño y La Niña en la Sabana de Bogotá durante el siglo XX. Cuadernos de Geografía, 16, 81-94.

Peralvo, M., Postigo, J., López,, S., 2010. Adaptación en Sistemas Productivos Andinos a los efectos del Cambio Climático: revisión y síntesis del estado del conocimiento, Serie Panorama Andino sobre Cambio Climático. CONDESAN, Lima-Quito.

Perez E. and Perez M., 2002. El sector rural en Colombia y su crisis actual. Cuadernos de Desarrollo Rural, 48. 35-58.

Perez, E., 1998. Una visión del desarrollo rural en Colombia. Cuadernos de Desarrollo Rural, 41. 7-20.

Perez, M.E., 2004. La conformación territorial en Colombia: entre el conflicto, el desarrollo y el destierro. Cuadernos de Desarrollo Rural, 51. 61-90.

Pesquera, A., Rodríguez, A., 2009. Impactos del actual TLC entre Estados Unidos y Colombia para los pequeños productores rurales: Pérdida de alternativas económicas y de seguridad alimentaria nacional. Oxfam GB, Oxford, UK.

Petras, J. and Veltmeyer, H., 2002. The peasantry and the state in Latin America: A troubled past, an uncertain future. The Journal of Peasant Studies, 29(3-4). 41-82. 
Pinilla, F., 2013. Impacto del Conflicto Armado Colombiano en la Producción Agrícola Nacional. Master thesis, Universidad de los Andes, Bogotá, Colombia.

Poveda, G., Álvarez, D., Rueda, Ó. (2011). Hydro-climatic variability over the Andes of Colombia associated with ENSO: a review of climatic processes and their impact on one of the Earth's most important biodiversity hotspots. Climate Dynamics, 36, 2233-2249.

Ramirez-Villegas, J., Salazar, M., Jarvis, A. \& Navarro-Racines, C. E., 2013. A way forward on adaptation to climate change in Colombian agriculture: perspectives towards 2050. Climatic Change, 115(3-4). 611628.

Riascos, A.J., Vargas, J.F., 2011. Violence and growth in Colombia: a review of the quantitative literature (No. 102), Documentos de trabajo. Faculty of Economics, University of Rosario, Bogota, Colombia.

Ribot, J., 2011. Vulnerability before adaptation: Toward transformative climate action. Global Environmental Change, 21. 1160-1162. DOI:10.1016/j.gloenvcha.2011.07.008.

Richani, N., 2012. The agrarian rentier political economy. Land Concentration and Food Insecurity in Colombia. Latin American Research Review, 47(2). 51-78.

Ruiz, J., 2010. Cambio climático en temperatura, precipitación y humedad relativa para Colombia usando modelos meteorológicos de alta resolución (Panorama 2011-2100). IDEAM, Bogotá, Colombia.

Ruiz, D., Martinson, D., \& Vergara, W. 2012. Trends, stability and stress in the Colombian Central Andes. Climatic Change, 112, 717-732. doi:10.1007/s10584-011-0228-0

Ruiz, D., Moreno, H.A., Gutiérrez, M.E., \& Zapata, P.A. 2008. Changing climate and endangered high mountain ecosystems in Colombia. Science of The Total Environment, 398, 122-132. doi:10.1016/j.scitotenv.2008.02.038

Ruiz, A. D. C. C., \& Caicedo, J. D. P. (2013). Efecto de los fenómenos de El Niño y La Niña en la precipitación y su impacto en la producción agrícola del departamento del Atlántico (Colombia). Cuadernos de Geografía-Revista Colombiana de Geografía, 22, 35-54.

Ryan, D., 2012. Informe sobre el Estado y Calidad de las Políticas Públicas sobre Cambio Climático y Desarrollo en América Latina. Plataforma Climatica Latinoamericana.

Santisteban, D.F., 2008. Colombia frente al posible Tradado de Libre Comercio con Estados Unidos. Analisis por sectores. Universitaria de Investigacion y Desarrollo, Bucaramanga, Colombia.

Scoones, I., 2009. Livelihoods perspectives and rural development. The Journal of Peasant Studies, 36(1). 171-196.

Seo, S. N. and Mendelsohn, R., 2008. A Ricardian analysis of the impact of climate change on South American farms. Chilean Journal of Agricultural Research, 68(1). 69-79.

Seo, S. N., 2010. A microeconometric analysis of adapting portfolios to climate change: adoption of agricultural systems in Latin America. Applied Economic Perspectives and Policy, 32(3). 489-514.

Seo, S. N., Mccarl, B. A. and Mendelsohn, R., 2010. From beef cattle to sheep under global warming? An analysis of adaptation by livestock species choice in South America. Ecological Economics, 69(12). 24862494. 
Silva, J.A., Eriksen, S. and Ombe, Z.A., 2010. Double exposure in Mozambique's Limpopo River Basin. The Geographical Journal, 176(1). 6-24.

Smit, B. and Wandel, J., 2006. Adaptation, adaptive capacity and vulnerability. Global Environmental Change, 16(3). 282-292.

Solarte, C., Martínez, A., Burgos, W., 2006. El TLC con Estados Unidos: efectos y retos para la cadena lácteas de Nariño. Tendencias, 7. 101-120.

Stoorvogel, J., Antle, J.M., Crissman, C.C., Bowen, W. 2004. The trade off analysis model: integrated biophysical and economic modeling of agricultural production systems. Agricultural Systems, 80(1). 43-66.

Thomson, F., 2011. The Agrarian Question and Violence in Colombia: Conflict and Development. Journal of Agrarian Change, 11. 321-356.

Trovar, J., 2011. El impacto esperado del Tratado de Libre Comercio entre Estados Unidos y Colombia. Puentes, 12. 3-4.

United Nations Development Programme (UNDP), 2003. El Conflicto, callejon con salida. National Report on Human Development, UNDP, Bogota.

United Nations Development Programme (UNDP), 2011. Colombia rural. Razones para la esperanza. National Report on Human Development, UNDP, Bogota.

United Nations Environment Programme (UNEP), 2005. Colombia: Integrated assessment of agricultural trade liberalization: With a focus on the corn sector. United Nations Environment Programme.

Vargas Cuervo, G. and Gómez, C., 2003. La Desertificación en Colombia y el Cambio Global. Cuadernos de Geografía, 12(1-2). 121-134.

Villareal, M.A., 2012. The U.S.-Colombia Free Trade Agreement: Background and Issues. Congressional Research Service, Washington DC, USA.

Westerhoff, L. and Smit, B., 2009. The rains are disappointing us: dynamic vulnerability and adaptation to multiple stressors in the Afram Plains, Ghana. Mitigation and Adaptation Strategies for Global Change, 14(4). 317-337.

Zapata-Caldas, E., Jarvis, A., Ramirez, J. and Lau, C., 2012. Potenciales impactos del Cambio Climático en cultivos andinos. Panorama Andino sobre Cambio Climático. Decision and Policy Analysis Program (DAPA).CONDESAN-SGCAN. Lima-Quito.

Hoyos, N., Escobar, J., Restrepo, J.C., Arango, A.M., \& Ortiz, J.C. (2013). Impact of the 2010-2011 La Niña phenomenon in Colombia, South America: The human toll of an extreme weather event. Applied Geography, 39, 16-25. doi:10.1016/j.apgeog.2012.11.018 
Feola, G., Agudelo Vanegas, L.A., Contesse Bamón, B.P., 2014. Colombian agriculture under multiple exposures: a review and research agenda. Climate and Development 1-15. doi:10.1080/17565529.2014.934776

Table 1. A typology of multiple exposures.

\begin{tabular}{|l|l|}
\hline Multiple exposure type & Description \\
\hline Outcome double exposure & $\begin{array}{l}\text { "The same units are exposed to the effects of both } \\
\text { globalization and global environmental change" (Leichenko } \\
\text { and O'Brien, 2008). }\end{array}$ \\
\hline Context double exposure & $\begin{array}{l}\text { "New conditions associated with both global } \\
\text { environmental change and globalization may change the } \\
\text { contextual environment and increase vulnerability to } \\
\text { shocks and stresses of all types" (Leichenko and O'Brien, } \\
\text { 2008). }\end{array}$ \\
\hline Feedback double exposure & $\begin{array}{l}\text { The change processes, outcomes and responses interact } \\
\text { over time whereby the feedbacks can result in an } \\
\text { amplification or dampening of the processes, and } \\
\text { consequent vulnerability. }\end{array}$ \\
\hline
\end{tabular}


Feola, G., Agudelo Vanegas, L.A., Contesse Bamón, B.P., 2014. Colombian agriculture under multiple exposures: a review and research agenda. Climate and Development 1-15. doi:10.1080/17565529.2014.934776

Table 2. Summary of the impacts of climate change on agriculture.

\begin{tabular}{|c|c|c|c|c|}
\hline Crop/Livestock & Indicators $^{1}$ & \begin{tabular}{|l} 
Expected \\
impact
\end{tabular} & Region/Department & Source \\
\hline Banana & $\begin{array}{l}\text { Crop suitability } \\
\text { Land availability } \\
\text { Niche losses }\end{array}$ & \begin{tabular}{|l|} 
Positive \\
Positive \\
Negative \\
\end{tabular} & $\begin{array}{l}\text { Andean region } \\
\text { Cundinamarca and Boyacá } \\
\text { National }\end{array}$ & \begin{tabular}{|l} 
Zapata-Caldas et al. (2012) \\
Eitzinger et al. (2012) \\
Ramirez-Villegas et al. (2013)
\end{tabular} \\
\hline Barley & $\begin{array}{l}\text { Exposure } \\
\text { Crop suitability }\end{array}$ & $\begin{array}{l}\text { Negative } \\
\text { Negative }\end{array}$ & $\begin{array}{l}\text { National } \\
\text { Andean region }\end{array}$ & $\begin{array}{l}\text { Ramirez-Villegas et al. (2013) } \\
\text { Zapata-Caldas et al. (2012) }\end{array}$ \\
\hline Beans & Land availability & Positive & Cundinamarca and Boyacá & Eitzinger et al. (2012) \\
\hline String bean & Land availability & Negative & Cundinamarca and Boyacá & Eitzinger et al. (2012) \\
\hline Blackberry & Land availability & Negative & Cundinamarca and Boyacá & Eitzinger et al. (2012) \\
\hline Carrots & Crop suitability & Negative & Andean region & Zapata-Caldas et al. (2012) \\
\hline Cassava & $\begin{array}{l}\text { Land availability } \\
\text { Exposure }\end{array}$ & \begin{tabular}{|l|} 
Negative \\
Negative
\end{tabular} & $\begin{array}{l}\text { Cundinamarca and Boyacá } \\
\text { National }\end{array}$ & \begin{tabular}{|l|} 
Eitzinger et al. (2012) \\
Ramirez-Villegas et al. (2013)
\end{tabular} \\
\hline Chicken & Suitability & Variable & National & Seo et al. (2010) \\
\hline Coarse grains & Productivity & Negative & National & Cline (2007) \\
\hline Cocoa & Exposure & Negative & National & Ramirez-Villegas et al. (2013) \\
\hline Coffee & $\begin{array}{l}\text { Land availability } \\
\text { Exposure }\end{array}$ & \begin{tabular}{|l|} 
Negative \\
Negative \\
\end{tabular} & $\begin{array}{l}\text { Cundinamarca and Boyacá } \\
\text { National }\end{array}$ & \begin{tabular}{|l|} 
Eitzinger et al. (2012) \\
Ramirez-Villegas et al. (2013)
\end{tabular} \\
\hline Cucumber & Crop suitability & Negative & Andean region & Zapata-Caldas et al. (2012) \\
\hline Dark tobacco & Exposure & Negative & National & Ramirez-Villegas et al. (2013) \\
\hline Diary cattle & Suitability & Variable & National & Seo et al. (2010) \\
\hline Flowers & Exposure & Negative & National & Ramirez-Villegas et al. (2013) \\
\hline Fruits & \begin{tabular}{|l|}
$\begin{array}{l}\text { Exposure } \\
\text { Land availability }\end{array}$ \\
\end{tabular} & $\begin{array}{l}\text { Negative } \\
\text { Negative }\end{array}$ & $\begin{array}{l}\text { National } \\
\text { Cundinamarca and Boyacá }\end{array}$ & $\begin{array}{l}\text { Ramirez-Villegas et al. (2013) } \\
\text { Eitzinger et al. (2012) }\end{array}$ \\
\hline Lettuce & Crop suitability & Negative & Andean region & Zapata-Caldas et al. (2012) \\
\hline Maize & $\begin{array}{l}\text { Land availability } \\
\text { Exposure }\end{array}$ & $\begin{array}{l}\text { Negative } \\
\text { Negative }\end{array}$ & $\begin{array}{l}\text { Cundinamarca and Boyacá } \\
\text { National }\end{array}$ & \begin{tabular}{|l} 
Eitzinger et al. (2012) \\
Ramirez-Villegas et al. (2013)
\end{tabular} \\
\hline Meat cattle & Suitability & Variable & National & Seo et al. (2010) \\
\hline Not specified & Household income & Negative & National & Seo and Mendelsson (2008) \\
\hline Oil seeds & Productivity & Negative & National & Cline (2007) \\
\hline Onion & Land availability & Positive & Cundinamarca and Boyacá & Eitzinger et al. (2012) \\
\hline Peas & $\begin{array}{l}\text { Land availability } \\
\text { Crop suitability }\end{array}$ & $\begin{array}{l}\text { Negative } \\
\text { Negative }\end{array}$ & $\begin{array}{l}\text { Cundinamarca and Boyacá } \\
\text { Andean region }\end{array}$ & \begin{tabular}{|l} 
Eitzinger et al. (2012) \\
Zapata-Caldas et al. (2012)
\end{tabular} \\
\hline Plantain & $\begin{array}{l}\text { Exposure } \\
\text { Crop suitability }\end{array}$ & \begin{tabular}{|l|} 
Negative \\
Positive
\end{tabular} & $\begin{array}{l}\text { National } \\
\text { Andean region }\end{array}$ & $\begin{array}{l}\text { Ramirez-Villegas et al. (2013) } \\
\text { Zapata-Caldas et al. (2012) }\end{array}$ \\
\hline Potato & $\begin{array}{l}\text { Productivity } \\
\text { Land availability } \\
\text { Crop suitability } \\
\text { Exposure } \\
\end{array}$ & \begin{tabular}{|l} 
Variable \\
Negative \\
Neutral \\
Negative \\
\end{tabular} & $\begin{array}{l}\text { National } \\
\text { Cundinamarca and Boyacá } \\
\text { Andean region } \\
\text { National }\end{array}$ & $\begin{array}{l}\text { Hijmans (2003) } \\
\text { Eitzinger et al. (2012) } \\
\text { Zapata-Caldas et al. (2012) } \\
\text { Ramirez-Villegas et al. (2013) }\end{array}$ \\
\hline Quinoa & Crop suitability & Negative & Andean region & Zapata-Caldas et al. (2012) \\
\hline Rice & $\begin{array}{l}\text { Productivity } \\
\text { Land availability } \\
\text { Exposure } \\
\text { Crop suitability } \\
\end{array}$ & \begin{tabular}{|l|} 
Negative \\
Positive \\
Negative \\
Positive \\
\end{tabular} & $\begin{array}{l}\text { National } \\
\text { Cundinamarca and Boyacá } \\
\text { National } \\
\text { Andean region }\end{array}$ & \begin{tabular}{|l} 
Cline (2007) \\
Eitzinger et al. (2012) \\
Ramirez-Villegas et al. (2013) \\
Zapata-Caldas et al. (2012)
\end{tabular} \\
\hline Sheep meat & Suitability & Variable & National & Seo et al. (2010) \\
\hline Sorghum & $\begin{array}{l}\text { Exposure } \\
\text { Crop suitability }\end{array}$ & \begin{tabular}{|l|} 
Negative \\
Positive
\end{tabular} & $\begin{array}{l}\text { National } \\
\text { Andean region }\end{array}$ & $\begin{array}{l}\text { Ramirez-Villegas et al. (2013) } \\
\text { Zapata-Caldas et al. (2012) }\end{array}$ \\
\hline Soybeans & $\begin{array}{l}\text { Productivity } \\
\text { Exposure }\end{array}$ & \begin{tabular}{|l|} 
Negative \\
Negative
\end{tabular} & $\begin{array}{l}\text { National } \\
\text { National }\end{array}$ & \begin{tabular}{|l|} 
Cline (2007) \\
Ramirez-Villegas et al. (2013) \\
\end{tabular} \\
\hline Sugarcane & $\begin{array}{l}\text { Land availability } \\
\text { Exposure }\end{array}$ & \begin{tabular}{|l|} 
Negative \\
Negative \\
\end{tabular} & $\begin{array}{l}\text { Cundinamarca and Boyacá } \\
\text { National }\end{array}$ & \begin{tabular}{|l|} 
Eitzinger et al. (2012) \\
Ramirez-Villegas et al. (2013)
\end{tabular} \\
\hline Tomato & $\begin{array}{l}\text { Land availability } \\
\text { Crop suitability }\end{array}$ & \begin{tabular}{|l|} 
Positive \\
Positive
\end{tabular} & $\begin{array}{l}\text { Cundinamarca and Boyacá } \\
\text { Andean region }\end{array}$ & \begin{tabular}{|l} 
Eitzinger et al. (2012) \\
Zapata-Caldas et al. (2012)
\end{tabular} \\
\hline
\end{tabular}


Feola, G., Agudelo Vanegas, L.A., Contesse Bamón, B.P., 2014. Colombian agriculture under multiple exposures: a review and research agenda. Climate and Development 1-15. doi:10.1080/17565529.2014.934776

\begin{tabular}{|l|l|l|l|l|}
\hline Ulluco & Crop suitability & Negative & Andean region & Zapata-Caldas et al. (2012) \\
\hline Wheat & Productivity & Neutral & National & Jones and Thornton (2003) \\
& Productivity & Negative & National & $\begin{array}{l}\text { Cline (2007) } \\
\text { Zapata-Caldas et al. (2012) }\end{array}$ \\
& Crop suitability & Negative & Andean region & Zapata-Caldas et al. (2012) \\
\hline Yuca & Crop suitability & Positive & Andean region &
\end{tabular}

1 Land availability = Land availability in highly favourable climate in 2050. 
Table 3. Summary of the impacts of trade liberalization on agriculture.*

\begin{tabular}{|c|c|c|c|}
\hline Crop/Produce & Indicators & Expected impact & Source \\
\hline Beans & $\begin{array}{l}\text { Exposure to competition with US, } \\
\text { price, cultivated area, production, } \\
\text { value of production }\end{array}$ & Negative & $\begin{array}{l}\text { MADR (2004), Lopez and } \\
\text { Saenz (2008), Garay et al. } \\
(2009)\end{array}$ \\
\hline Bovine meat & Competition with US & Positive (conditional) & $\begin{array}{l}\text { MADR } 2004 \\
\text { Gil Quintero (2008) }\end{array}$ \\
\hline Carrots & Price, value of production & Negative & Garay et al. (2009) \\
\hline Cereals & Decrease in production & Negative & Gracia and Zuleta (2005) \\
\hline Cotton & Exposure to competition with US & Negative & MADR (2004) \\
\hline Fruit & Exposure to competition with US & \begin{tabular}{|l|} 
Positive (conditional) \\
Negative in Bolívar
\end{tabular} & $\begin{array}{l}\text { MADR (2004), CCB (2007), } \\
\text { Lopez and Saenz (2008) }\end{array}$ \\
\hline Maize & $\begin{array}{l}\text { Prices, cultivated area, production, } \\
\text { value of production, income for } \\
\text { producers, workforce employed, } \\
\text { workers income }\end{array}$ & Negative & $\begin{array}{l}\text { UNEP (2005), Garay et al. } \\
\text { (2009) }\end{array}$ \\
\hline Milk & Exposure to competition with US & Positive in Nariño (conditional) & Solarte et al., (2006) \\
\hline Oil seeds & $\begin{array}{l}\text { Exposure to competition with US, } \\
\text { decrease in production }\end{array}$ & Negative & $\begin{array}{l}\text { MADR (2004), Gracia and } \\
\text { Zuleta (2005), Lopez and } \\
\text { Saenz (2008) }\end{array}$ \\
\hline Onion & Price, value of production & Negative & Garay et al. (2009) \\
\hline Peas & $\begin{array}{l}\text { Price, cultivated area, production, } \\
\text { value of production }\end{array}$ & Negative & Garay et al. (2009) \\
\hline Pork meat & $\begin{array}{l}\text { Price, production, value of } \\
\text { production }\end{array}$ & Negative & Garay et al. (2009) \\
\hline Poultry meat & $\begin{array}{l}\text { Exposure to competition with US, } \\
\text { price, production, value of } \\
\text { production }\end{array}$ & Negative & $\begin{array}{l}\text { MADR (2004), Garay et al. } \\
(2009)\end{array}$ \\
\hline Rice & $\begin{array}{l}\text { Exposure to competition with US, } \\
\text { price, cultivated area, production, } \\
\text { value of production }\end{array}$ & Negative & $\begin{array}{l}\text { MADR (2004), Garay et al. } \\
(2009)\end{array}$ \\
\hline Sorghum & $\begin{array}{l}\text { Price, cultivated area, production, } \\
\text { value of production }\end{array}$ & Negative & $\begin{array}{l}\text { Garay et al. (2009), Lopez } \\
\text { and Saenz (2008) }\end{array}$ \\
\hline Sugar & Exposure to competition with US & Positive (conditional) & MADR (2004) \\
\hline Tobacco & Exposure to competition with US & Positive (conditional) & MADR (2004) \\
\hline Tomato & Price, value of production & Negative & Garay et al. (2009) \\
\hline Vegetables & Exposure to competition with US & $\begin{array}{l}\text { Positive (conditional) } \\
\text { Negative in Bolívar }\end{array}$ & $\begin{array}{l}\text { MADR (2004), CCB (2007), } \\
\text { Lopez and Saenz (2008) }\end{array}$ \\
\hline Wheat & $\begin{array}{l}\text { Price, cultivated area, production, } \\
\text { value of production }\end{array}$ & Negative & Garay et al. (2009) \\
\hline
\end{tabular}

* Highly unequal spatial (department) and social (small-, and largeholders) distribution of positive and negative impacts (UNEP, 2005; Arguello, 2009; Pesquera and Rodriguez, 2009; Garay et al., 2009; see also Ramirez-Villegas et al., 2013) 
Feola, G., Agudelo Vanegas, L.A., Contesse Bamón, B.P., 2014. Colombian agriculture under multiple exposures: a review and research agenda. Climate and Development 1-15. doi:10.1080/17565529.2014.934776

Table 4. Summary of indicators of violent conflict in Colombian departments.

\begin{tabular}{|l|l|l|}
\hline $\begin{array}{l}\text { Departments with major effects of } \\
\text { violent conflict }\end{array}$ & $\begin{array}{l}\text { Departments with effects of violent } \\
\text { conflict }\end{array}$ & $\begin{array}{l}\text { Departments with minor effects of } \\
\text { violent conflict }\end{array}$ \\
\hline $\begin{array}{l}\text { Antioquia, Arauca, Bolívar, Caquetá, } \\
\text { Cauca, César, Chocó, Córdoba, Guaviare, } \\
\text { La Guajira, Magdalena, Meta, Nariño, }\end{array}$ & $\begin{array}{l}\text { Altlántico, Caldas, Casanare, Huila, } \\
\text { Quindío, Risaralda, Santander, Vichada, }\end{array}$ & $\begin{array}{l}\text { Amazonas, Boyacá, Cundinamarca, } \\
\text { Guainía, San Andrés, Providencia, } \\
\text { Vaupés }\end{array}$ \\
$\begin{array}{l}\text { Torte de Santander, Putumayo, Vulle del Cauca, } \\
\text { Tolima, }\end{array}$ & & \\
\hline
\end{tabular}


Feola, G., Agudelo Vanegas, L.A., Contesse Bamón, B.P., 2014. Colombian agriculture under multiple exposures: a review and research agenda. Climate and Development 1-15. doi:10.1080/17565529.2014.934776

Table 5. Adaptation measures recommeded to respond to different stressors.

\begin{tabular}{|l|l|l|l|}
\hline \multicolumn{2}{|c|}{ Stressor: climate change } & \multicolumn{2}{c|}{ Stressor: trade liberalization } \\
\hline Adaptation measure & Source & Adaptation measure & Source \\
\hline $\begin{array}{l}\text { Technological development, } \\
\text { extension and technology } \\
\text { transfer }\end{array}$ & $\begin{array}{l}\text { Zapata-Caldas et al. (2012), } \\
\text { Ramirez-Villegas et al. (2013) }\end{array}$ & $\begin{array}{l}\text { Infrastructural improvement } \\
\text { (roads, ports, storage) }\end{array}$ & $\begin{array}{l}\text { Gracia and Zuleta (2005), CCB } \\
\text { (2007), Arguello (2009), } \\
\text { Martincus and Gomez (2009) }\end{array}$ \\
\hline $\begin{array}{l}\text { Information and impact } \\
\text { assessment }\end{array}$ & $\begin{array}{l}\text { Zapata-Caldas et al. (2012), } \\
\text { Ramirez-Villegas et al. (2013) }\end{array}$ & $\begin{array}{l}\text { Increase te share of skilled } \\
\text { workforce }\end{array}$ & $\begin{array}{l}\text { Gracia and Zuleta (2005), } \\
\text { Martincus and Gomez (2009) }\end{array}$ \\
\hline Crop insurance schemes & $\begin{array}{l}\text { Zapata-Caldas et al. (2012), } \\
\text { Ramirez-Villegas et al. (2013) }\end{array}$ & $\begin{array}{l}\text { Improvement of productive } \\
\text { processes' efficiency }\end{array}$ & Garay et al., 2009 \\
\hline $\begin{array}{l}\text { Shift to different } \\
\text { crop/livestock/farming } \\
\text { system }\end{array}$ & Seo (2010), Seo et al. (2010) & $\begin{array}{l}\text { Improvement of productive } \\
\text { processes' health and } \\
\text { phytosanitary standards }\end{array}$ & Solarte et al. (2006) \\
\hline Inter-institutional network & Ramirez-Villegas et al. (2013) & Value chain coordination & CCB (2007) \\
\hline
\end{tabular}


Feola, G., Agudelo Vanegas, L.A., Contesse Bamón, B.P., 2014. Colombian agriculture under multiple exposures: a review and research agenda. Climate and Development 1-15. doi:10.1080/17565529.2014.934776

\section{Figure 1. Map of Colombia.}

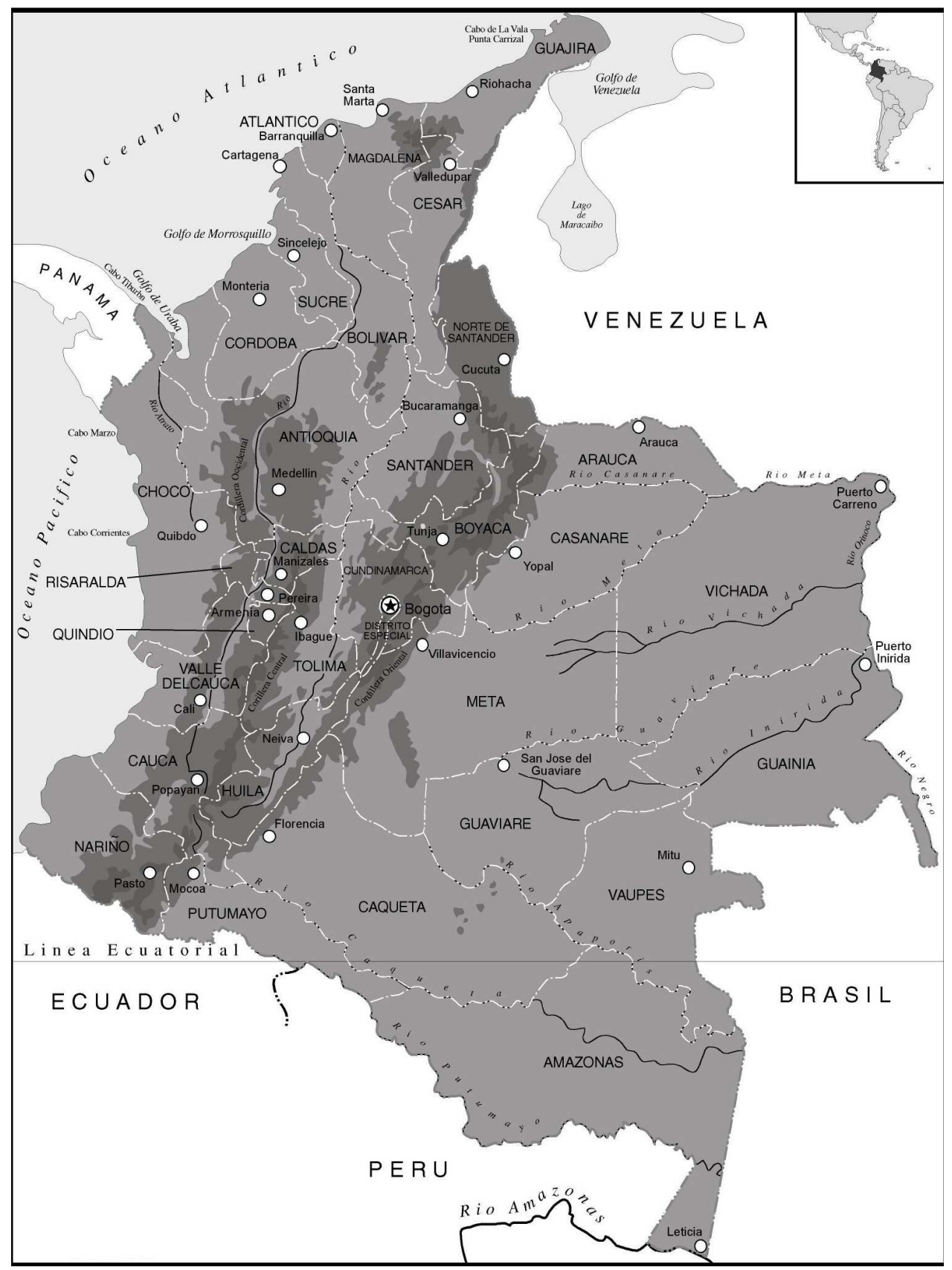

